\title{
Combined Gene and Protein Expression of Hormone- Sensitive Lipase and Adipose Triglyceride Lipase, Mitochondrial Content, and Adipocyte Size in Subcutaneous and Visceral Adipose Tissue of Morbidly Obese Men
}

\author{
Hélène De Naeyer ${ }^{a, d} \quad$ D. Margriet Ouwens ${ }^{b} \quad$ Yves Van Nieuwenhove $^{a} \quad$ Piet Pattyn $^{a}$ \\ Leen M. 't Hart ${ }^{\mathrm{c}}$ Jean-Marc Kaufman ${ }^{\mathrm{d}}$ Henrike Sell $^{\mathrm{b}}$ Juergen Eckel ${ }^{\mathrm{b}}$ Claude Cuvelier $^{\mathrm{e}}$ \\ Youri E. Taes ${ }^{\mathrm{d}}$ Johannes B. Ruige ${ }^{\mathrm{d}^{*}}$ \\ aDepartment of Abdominal Surgery, University Hospital, Ghent, Belgium \\ ${ }^{\mathrm{b}}$ German Diabetes Center, Institute for Clinical Biochemistry and Pathobiochemistry, Düsseldorf, Germany \\ 'Molecular Cell Biology and Molecular Epidemiology, Leiden University Center, Leiden, the Netherlands \\ dDepartment of Endocrinology,

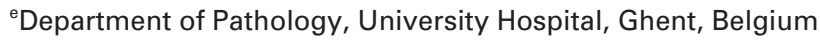

\section{Keywords}

Mitochondrial content · Hormone-sensitive lipase ·

Adipose triglyceride lipase - Obesity · Lipolysis .

Metabolic diseases

\section{Summary}

Aims: Lipotoxicity in obesity might be a failure of adipocytes to respond sufficiently adequate to persistent energy surplus. To evaluate the role of lipolytic enzymes or mitochondria in lipotoxicity, we studied expression levels of genes and proteins involved in lipolysis and mitochondrial DNA (mtDNA) content. Methods: As differences in lipid metabolism between men and women are extremely complex, we recruited only men (lean and morbidly obese) and collected subcutaneous and visceral adipose tissue during abdominal surgery for real-time PCR gene expression, protein expression, and microscopic study. Results: Although mRNA levels of hormone-sensitive lipase (HSL) and adipose triglyceride lipase (ATGL) were increased in visceral adipose tissue of morbidly obese men, this was not paralleled by alterations in protein expression and phosphorylation of HSL and ATGL. mtDNA content of visceral adipose tissue was increased in morbidly obese men as compared to lean controls $(p<0.013)$. Positive correlations were observed between visceral adipocyte size and serum tria- cylglycerol $(r=0.6, p<0.007)$ as well as between visceral adipocyte size and CRP $(r=0.6, p<0.009)$ in analyses performed separately in obese men. Conclusion: Lipotoxicity of morbidly obese men might be related to the quantitative impact of the visceral fat depot rather than to important dysregulation of involved lipolytic enzymes or adipocyte mitochondria.

\section{Introduction}

Obesity is a major risk factor for the development of type 2 diabetes and cardiovascular diseases. Yet, about $20-30 \%$ of obese individuals do not develop metabolic complications [1]. In lean persons, adipocytes protect against lipotoxicity, as is observed in patients with lipodystrophy who have hardly adipose tissue though similar metabolic complications as severe obese persons [2]. Adipose tissue plays a crucial role in handling the flux of fatty acids (FA) in the circulation in the postprandial period $[3,4]$. Adipose tissue may provide its buffering action by suppressing the release of non-esterified FA into the circulation and by increasing triacylglycerol (TG) clearance [5]. With expansion of adipose tissue, one supposes that this capacity also increases. Failure of this capacity might

\section{KARGER \\ Fax +497614520714 \\ Information@Karger.de}

www.karger.com (c) 2011 S. Karger GmbH, Freiburg

1662-4025/11/0045-0407\$38.00/0

Accessible online at:

www.karger.com/ofa
Dr. Johannes B. Ruige

Department of Endocrinology, Ghent University Hospital

De Pintelaan 185, Building 9 K12, Ghent, Belgium

Tel. +32 9 332-6861, Fax -3897

johannes.ruige@ugent.be 
cause excessive fluxes of lipid fuels which could accumulate in the form of TG and result in formation of toxic lipid metabolites like ceramides, leading to insulin resistance $[3,6]$.

Metabolic complications of obesity are related to the distribution of body fat. Android obesity, characterized by storage of fat especially in the abdominal (visceral) region, shows an increased risk for metabolic complications, whereas gynoid obesity, characterized by storage of fat in the subcutaneous gluteo-femoral region, is protective [7-10]. In general, adipocytes seem to increase their lipid storage and buffer capacity through hypertrophy (enlargement of the adipocyte size) and hyperplasia (increase in number of adipocytes). The adipocyte size is important for metabolic complications: hypertrophy of subcutaneous adipocytes has been shown to predict diabetes, independent from insulin resistance [11, 12]. Adipocyte size is also positively associated with adipocyte death, macrophage infiltration, and secretion of pro-inflammatory adipokines, contributing to metabolic derangement $[13,14]$. Whether or not the human adipocyte mitochondria are important for metabolic complications is hardly studied, despite the potential possibility of a protective effect against insulin resistance, by FA-induced mitochondrial uncoupling $[15,16]$. The role of key enzymes involved in lipolysis and adaptation of subcutaneous and visceral adipose tissue is contradictory [17-24]. The breakdown of stored TG into FA is largely regulated by hormone-sensitive lipase (HSL) and adipose triglyceride lipase (ATGL). Most of the lipolysis studies were heterogeneous, especially with respect to gender, despite complex differences between male and female lipid metabolism and adipose tissue.

We therefore performed (to our knowledge) the first maleonly study to evaluate the importance of key enzymes involved in lipolysis and adipocyte mitochondria for lipotoxicity. Subcutaneous and visceral adipose tissue were both evaluated, as a recently reported direct relationship between the visceral fat depot and hepatic oxidation of FA underlines the importance of visceral adipose tissue [25].

\section{Participants and Methods}

Subjects

31 morbidly obese men undergoing bariatric surgery and 19 normalweight control men undergoing abdominal surgery were recruited. Men from the control group underwent surgery for adhesiolysis, rupture of the stomach, intestinal resection, or stomach closing. Three control men with increased C-reactive protein were excluded ( $>2 \mathrm{mg} / \mathrm{dl})$. The morbidly obese men were divided in men with and without diabetes mellitus type 2 . Diabetes mellitus type 2 or its preceding stage was defined according to recent criteria [26]. None of these men used thiazolidinediones, though most of the type 2 diabetes patients were on metformin therapy or used additionally sulfonylurea or insulin. Metformin and sulfonylurea were discontinued $24 \mathrm{~h}$ before operation. Subjects gave written informed consent to participate in this study, which was approved by the Ethical Review Board of the Ghent University Hospital and conducted according to the principles of the Declaration of Helsinki (Registration no B67020084018).

\section{Anthropometric Parameters and Blood Sampling}

Anthropometric measurements were performed during pre-operative examination. Body composition was estimated by bioimpedance (Bodystat 1500, Bodystat, Ltd, Isle of Man, UK). Waist and hip circumferences were measured according to standard procedures at the umbilicus and the gluteal region in standing position, respectively. Prior to the operation, fasting blood samples were collected from the patients before 10:00 am. The samples were centrifuged, fractionated and stored by $-80{ }^{\circ} \mathrm{C}$ until analysis. Fasting serum TG (glycerol kinase-based method), glucose (hexokinase-based method) were determined colorimetrically (Modular, Roche Diagnostics, Grenzach-Whylen, Germany), and insulin serum concentrations were determined using an electrochemoluminescent immunoassay (modular immunoassay, Roche Diagnostics). Intra- and interassay coefficients of variation $(\mathrm{CV})$ for all parameters were less than 3 and $6 \%$, respectively.

\section{Adipose Tissue Processing}

Visceral and subcutaneous adipose tissue specimens were obtained from the patients at the end of the surgical intervention. These biopsies were stored immediately at $-80{ }^{\circ} \mathrm{C}$ until RNA isolation for RT-PCR expression analysis. Two fractions from each site were stored in PG (4\% paraformaldehyde and $5 \%$ glutaraldehyde in $0.2 \mathrm{~mol} / 1$ sodium cacodylate buffer $\mathrm{pH}$ 7.4 , at $4{ }^{\circ} \mathrm{C}$ ) and in formol (at room temperature) for further microscopic analysis. Adipose tissue was fixed in buffered $4 \%$ formol solution (Klinipath, Olen, Belgium) at room temperature. Further fixation, dehydration, cleaning and paraffin impregnation of tissues was performed (Tissue Tek Vip, Sakura, CO, USA) and tissues were embedded with TBS 88 Paraffin Embedding System (Medite, Winter Garden, FL, USA). Haematoxylineosin staining and film coverslipping of $3 \mu \mathrm{m}$ slides was completed by a Tissue Tek Prisma (Sakura). Adipocyte size was assessed by using the approach of Tchoukalova et al. [27]. Digital photographs of the paraffin slides were taken with a Mirax Midi camera (Zeiss, Jena, Germany) and the average surface area of 10 adipocytes of each slide was calculated using the Mirax Viewer software (Zeiss). RNA was isolated out of $100 \mathrm{mg}$ of the above described fat biopsies using the Tripure Isolation Reagent kit (Roche Diagnostics, Grenzach-Whylen) according to the manufacturer's instructions. The RNase-Free DNase Set (Qiagen, Venlo, the Netherlands) was used to remove contaminating genomic DNA. The isolated RNA was cleaned up using the RNeasy Mini Kit (Qiagen). Efficiency and quality of the RNA isolation was determined by measuring the RNA concentration with a NanoDrop ND-2000 Spectrophotometer (Thermo Fisher Scientific, Erembodegem, Belgium). All samples with a 260/280 $\mathrm{nm}$ absorbance ratio approaching 2 were considered to be pure RNA.

Quantitative cDNA synthesis was carried out using the SuperScript First-Strand Synthesis System for RT-PCR kit (Invitrogen, Gent, Belgium) according to the manufacturer's instructions. Measurements of relative gene expression of LPL, HSL, and ATGL in both subcutaneous and visceral fat biopsies were performed on a lightcycler 480 (Roche). RT-PCR reaction mixtures $(7.5 \mu \mathrm{l})$ contained $3 \mathrm{ng}$ template cDNA, $300 \mathrm{nmol} / \mathrm{l}$ forward and reverse primer and $3.75 \mu \mathrm{l} \mathrm{SYBR}$ Green PCR Master Mix (Applied Biosystems, Foster City, CA, USA). The cycling conditions comprised a polymerase activation at $95{ }^{\circ} \mathrm{C}$ for $10 \mathrm{~min}$ followed by 45 cycles at $95{ }^{\circ} \mathrm{C}$ for $15 \mathrm{~s}$ atd $60{ }^{\circ} \mathrm{C}$ for $30 \mathrm{~s}$ and $72{ }^{\circ} \mathrm{C}$ for $30 \mathrm{~s}$. Data were obtained as threshold cycle $(\mathrm{Ct})$ values. Primer sequences were designed using Primer Express software 3.0 (Applied Biosystems) or were adapted from literature [17] (see table 1 for primer sequences). Melting curve analysis confirmed the amplification of the expected genespecific product and absence of primer dimers. PCR efficiencies were between 90 and $110 \%$. All genes of interest were normalized using the normalization factor calculated by the geNorm VBA applet for Microsoft Excel version 3.5. [28]. Raw gene expression levels were calculated via the delta-Ct method according to the geNorm manual. Determination of the average pairwise variation $\mathrm{V}$ for each gene resulted in $18 \mathrm{~S}$ rRNA, eF1 $\alpha$ and ATP5O as the most stable reference genes $(\mathrm{V}<0.15)$. 
Table 1. Sequences of the primers

\begin{tabular}{lll}
\hline & Forward primer $\left(5^{\prime}-3^{\prime}\right)$ & Reverse primer (5'-3') \\
\hline Gene & & \\
EF1 $\alpha$ & CTG-GCA-AGG-TCA-CCA-AGT-CT & CCG-TTC-TTC-CAC-CAC-TGA-TT \\
18s rRNA & GAT-GGG-CGG-CGG-AAA & CTT-CGG-CCC-ACA-CCC-TTA-A \\
ATP5O & AGG-CCT-CCT-GTT-CAG-GTA-TAC-G & CTT-GCT-CCA-GCT-TAT-TCT-GTT-TTG \\
LPL & TGC-CCT-AAG-GAC-CCC-TGA-A & TGA-CAG-GTA-GCC-ACG-GAC-TCT \\
HSL & CTC-AGT-GTG-CTC-TCC-AAG-TG & CAC-CCA-GGC-GGA-AGT-CTC \\
ATGL & GCT-GGT-GCC-AAG-TTC-ATT-GA & TGG-CAT-GCT-CAT-GGC-TAT-CA \\
\hline MtDNA content & & \\
LPL & GACTGGCCTGCCCAATTGT & GAGCCAGAACTGTCTTTATTCAAGTG \\
ND1 & CACCAAAGAGCCCCTAAAACC & AGAAGAGCGATGGTGAGAGCTAA \\
\hline
\end{tabular}

Table 2. Clinical and biochemical characteristics of lean and obese men

\begin{tabular}{|c|c|c|c|c|}
\hline & $\begin{array}{l}\text { Controls } \\
(\mathrm{n}=16)\end{array}$ & $\begin{array}{l}\text { Obese } \\
(\mathrm{n}=8)\end{array}$ & $\begin{array}{l}\text { Obese }+ \text { diabetes } \\
\text { mellitus type } 2 \\
(\mathrm{n}=23)\end{array}$ & $\mathrm{p}$ value \\
\hline \multicolumn{5}{|l|}{ Characteristics } \\
\hline Age, years & $52(14)$ & $40(13)$ & $54(11)$ & 0.027 \\
\hline Weight, kg & $73(13)$ & $141(30)$ & $144(20)$ & 0.0001 \\
\hline $\mathrm{BMI}, \mathrm{kg} / \mathrm{m}^{2}$ & $23(3)$ & $41(7)$ & $46(6)$ & 0.0001 \\
\hline Fat mass, $\%$ & $24(3)$ & $37(6)$ & $44(6)$ & 0.0001 \\
\hline Plasma glucose, $\mathrm{mg} / \mathrm{dl}$ & $0.82(0.15)$ & $0.92(0.06)$ & $1.48(0.52)$ & 0.0001 \\
\hline Plasma insulin, IU/l & $5(3-6.8)$ & $25(15-28)$ & $35(23-47)$ & 0.0001 \\
\hline $\mathrm{CRP}, \mathrm{mg} / \mathrm{dl}$ & $1.6(1.2-2.1)$ & $3.9(1.5-6.5)$ & $2.6(2.1-4.1)$ & 0.012 \\
\hline Fasting serum triglycerides, $\mathrm{mg} / \mathrm{dl}$ & $101(80-154)$ & $133(90-285)$ & $148(105-173)$ & 0.25 \\
\hline \multicolumn{5}{|l|}{ MtDNA content } \\
\hline Visceral adipose tissue & $0.80(0.53-1.06)$ & $1.21(0.96-1.39)$ & $1.24(0.88-1.78)$ & 0.013 \\
\hline Subcutaneous adipose tissue & $1.06(0.79-1.16)$ & $1.35(0.93-1.44)$ & $0.98(0.88-1.77)$ & 0.24 \\
\hline \multicolumn{5}{|l|}{ Adipocyte size, $\mu m^{2}$} \\
\hline Visceral adipocyte size & $4,584(2,127)$ & $8,558(2,648)$ & $8,143(2,281)$ & 0.0001 \\
\hline Subcutaneous adipocyte size & $4,484(1,615)$ & $8,642(1,761)$ & $9,829(1,355)$ & 0.0001 \\
\hline
\end{tabular}

\section{Analysis of mitochondrial DNA Content}

DNA was isolated from $100 \mathrm{mg}$ adipose tissue using the QIAamp DNA mini kit. The amount of mitochondrial DNA (mtDNA) was quantified by real-time PCR as described previously [29, 30]. Briefly, the relative amount of mtDNA was quantified by comparison with a nuclear target, which was the lipoprotein lipase gene. A fragment of mtDNA was amplified between nucleotide positions 3,780 and 3,842, which is located in MT-ND1 on the heavy strand transcript (see table 1 for primer sequences). Quantitative real-time PCR was performed using a StepOne Plus real time PCR system (Applied Biosystems) using SYBR Green PCR Master Mix (Applied Biosystems). For quantification, reference curves that were serial dilutions of a standard DNA were used. A ratio between mtDNA and LPL was calculated (mtDNA/LPL), which reflects the tissue concentration of mitochondrial content.

\section{Analysis of Protein Expression and Phosphorylation}

For protein analysis, $200 \mathrm{mg}$ of the biopsies was homogenized in $50 \mathrm{mmol} /$ Tris. $\mathrm{HCl}$ (pH 7.5); $150 \mathrm{mmol} / \mathrm{l} \mathrm{NaCl} ; 0.5 \%$ Triton X-100; $1 \mathrm{mmol} / \mathrm{l} \mathrm{NaF}$; $1 \mathrm{mmol} / 1 \mathrm{Na}_{3} \mathrm{VO}_{4} ; 2 \mathrm{mmol} / 1 \mathrm{MgCl}_{2}, 1 \mathrm{mmol} / \mathrm{l} \mathrm{DTT}$; and protease inhibitors (Complete, Roche Diagnostics) using an ultraturrax homogenizer. Homogenates were cleared by centrifugation $\left(15 \mathrm{~min} ; 12,000 \mathrm{rpm} ; 4^{\circ} \mathrm{C}\right)$, and protein content was determined using Bradford reagent (Biorad Lab- oratories, Munich, Germany). $5 \mu \mathrm{g}$ of protein was loaded onto SDS-Page gels and transferred to polyvinylidene difluoride (PVDF) membranes. After blotting, membranes were blocked with Tris-buffered saline (TBS), containing $0.1 \%$ Tween 20 , and $5 \%$ non fat dry milk for $2 \mathrm{~h}$ at room temperature and then incubated overnight at $4{ }^{\circ} \mathrm{C}$ with polyclonal antibodies recognizing ATGL, HSL, phospho-HSL-Ser563, phospho-HSL-Ser565, and phospho-HSL-Ser660 (all from Cell Signaling Technology, Danvers, MA, USA). After washing, membranes were incubated with secondary HRP-conjugated antibody for $2 \mathrm{~h}$ at room temperature and washed again. Bound antibodies were visualized using enhanced chemoluminescence and quantified by using a Versadoc system (Roche Diagnostics). Values were normalized for protein expression by reprobing the membranes with antibodies for GAPDH (Abcam).

\section{Statistical Analyses}

Variables were described as mean $\pm \mathrm{SD}$, or median (first, third quartile) in case of non-Gaussian distribution. Comparisons between groups were performed using one way analysis of variance or Kruskal-Walliss with Dunn's multiple comparison test, if appropriate. If not normally distributed (Kolmogorov-Smirnov test), variables underwent a logarithmic transformation prior to calculation of the Pearson correlation coefficient, which was performed separately for lean control or morbidly obese men, 
a

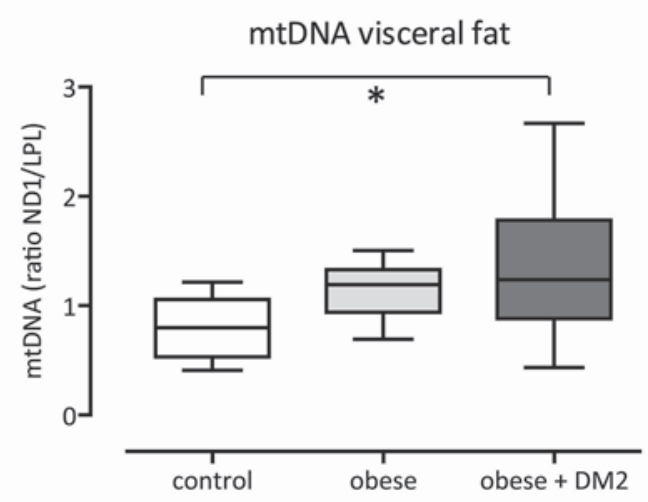

C

Fig. 1. mtDNA content obtained from adipose tissue of lean control, obese and obese + diabetes mellitus type 2 men of visceral (a) and the subcutaneous depot (b). Correlation $(\mathrm{r}=0.6, \mathrm{p}<0.007)$ between the size of visceral adipocytes and serum TG in obese men (c), and correlation $(\mathrm{r}=0.6$, $\mathrm{p}<0.03$ ) between the size of subcutaneous adipocytes and serum TG in lean men (d). Correlation $(\mathrm{r}=0.6$, $\mathrm{p}<0.009$ ) between the size of visceral adipocytes and CRP in obese men (e). $* \mathrm{p}<0.05$.

e

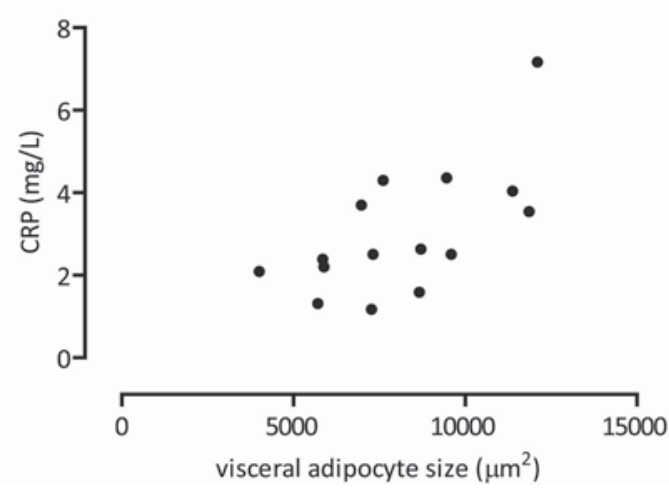

b

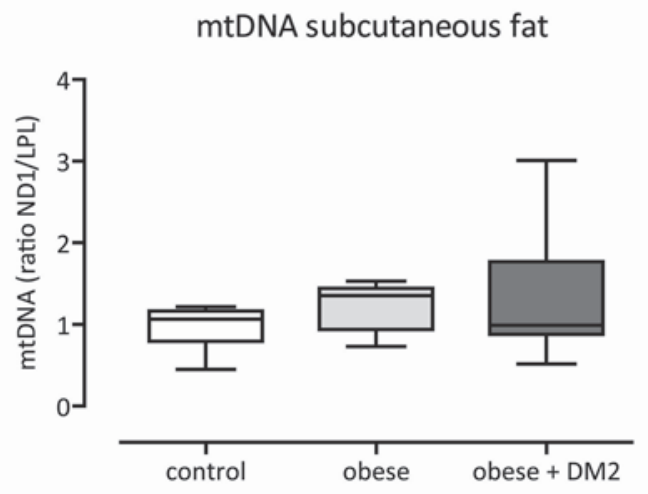

d

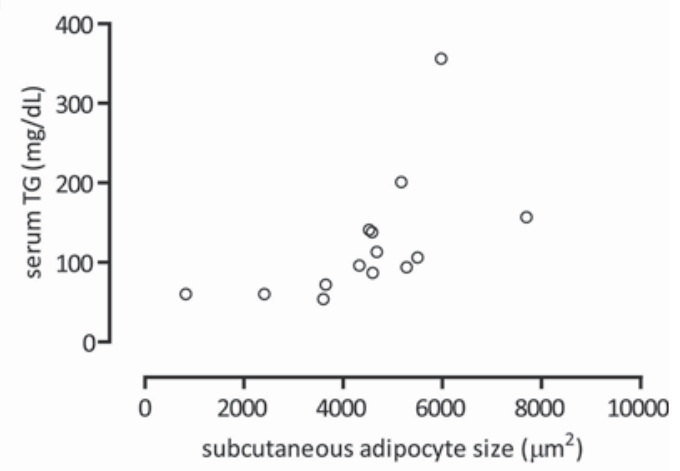

as the two groups are on the opposite side of the normal spectrum. Subjects using fibrate drugs were excluded from statistical analysis including serum TG concentrations. A p value of $<0.05$ (two-tailed) was considered as statistical significant. The statistical procedures were performed using SPSS 18.0 software package (SPSS Inc., Chicago, IL, USA).

\section{Results}

\section{General Characteristics}

Anthropometric and biochemical characteristics of the study population are summarized in table 2 . Age was slightly different between the groups; lean men were $52 \pm 14$ years, obese men were $40 \pm 13$ years, and obese men with diabetes mellitus type 2 were $54 \pm 11$ years $(\mathrm{p}<0.027)$. Weight, BMI, and fat mass were markedly higher in the obese state. mtDNA content was significantly increased in visceral adipose tissue of the obese group (ND1/LPL ratio: 0.80 in controls, 1.21 in obese men, and 1.24 in obese men with diabetes mellitus type $2 ; \mathrm{p}<0.013$ ) (table 2; fig. 1a). In subcutaneous adipose tissue, differences in mtDNA content were not observed (table 2; fig. 1b). Microscopic measurements showed significantly larger adipocytes in the obese subjects in both the subcutaneous and visceral adipose depot $(\mathrm{p}<0.0001$; table 1 ; fig. 2$)$. Correlates of adipocyte size were calculated in separate analyses for lean controls and morbidly obese men, as the two groups are on the opposite side of the normal spectrum. In morbidly obese men, the size of the visceral adipocytes correlated to serum TG (fig. $1 \mathrm{c} ; \mathrm{r}=0.6, \mathrm{p}<0.007$ ), and to CRP 


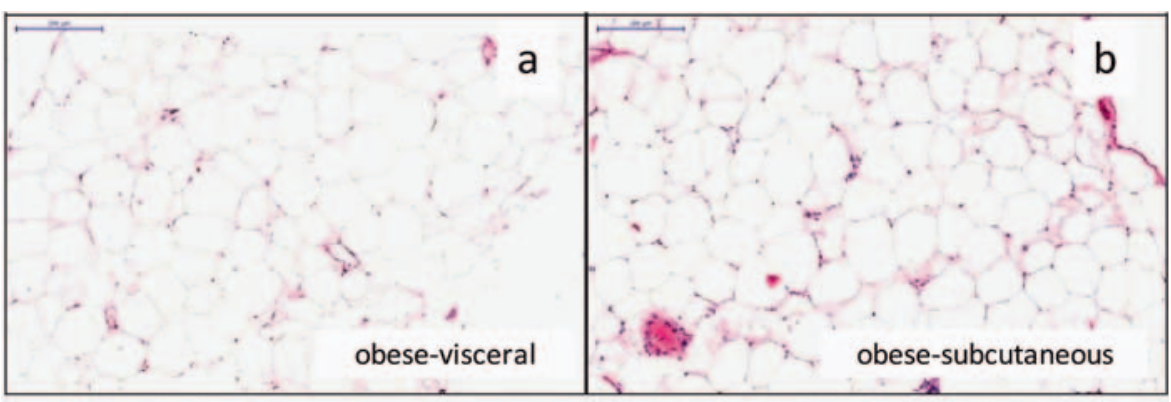

Fig. 2. Haematoxylin-eosin (original magnification $\times 40)$ stained sections of visceral $(\mathbf{a})$ and subcutaneous (b) adipocytes of morbidly obese males, and visceral (c) and subcutaneous (d) adipocytes of control males. The scale bar indicates $200 \mu \mathrm{m}$.

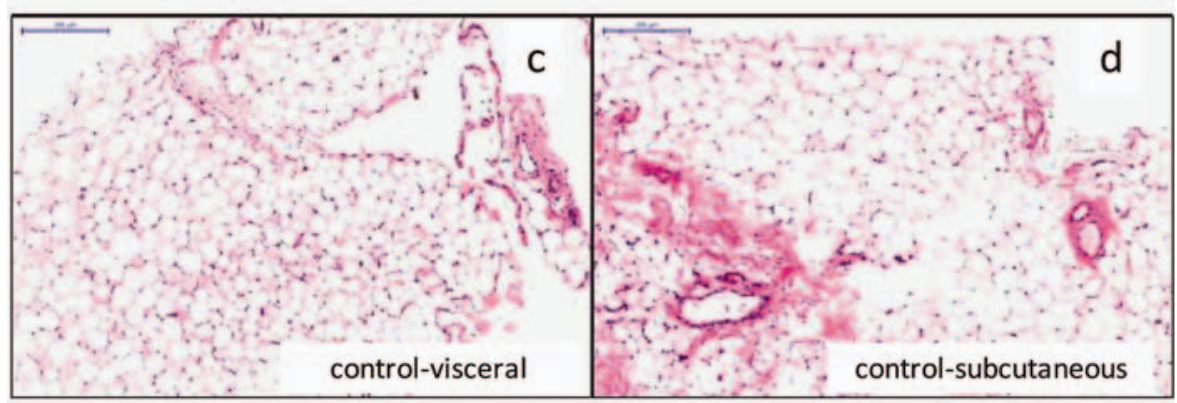

(fig. 1e; $r=0.6, p<0.009$ ). In lean men, the size of the subcutaneous adipocytes correlated to serum TG (fig. $1 \mathrm{~d} ; \mathrm{r}=0.6$, $\mathrm{p}<0.03)$.

\section{mRNA Expression Levels of Genes Involved in Lipogenesis} and Lipolysis

Real-time PCR gene expression analysis of LPL, HSL, and ATGL in both abdominal subcutaneous adipose tissue and visceral adipose tissue are presented in figure 3a-f. Expression levels of LPL, HSL, and ATGL tend to be higher in visceral adipose tissue of the obese group without diabetes mellitus type 2 . Yet, statistically significantly differences were established for HSL and ATGL mRNA expressions (HSL visceral fat: $p<0.006$; ATGL visceral fat: $p<0.003)$. In the subcutaneous depot, differences of expression levels of LPL, HSL, and ATGL between obese and lean men were not found.

\section{Expression of Proteins Involved in Lipolysis}

Protein expression of HSL and ATGL were determined. Additionally, phosphorylation of pHSL on Ser563 (inhibitory), SerP565, and Ser660 was assessed in subcutaneous and visceral adipose tissue of the subjects. In general, no statistical significant difference of protein expression and phosphorylation levels were observed between lean controls and morbidly obese men with or without diabetes mellitus type 2 (fig. 4a-f, $5 a-h)$.

Unexpectedly, in lean men, the size of visceral adipocytes correlated consistently positive with expression levels of ATGL mRNA and HSL mRNA in subcutaneous adipose tissue (fig. $3 \mathrm{~g} ; \mathrm{r}=0.6, \mathrm{p}<0.02$; fig. $3 \mathrm{~h} ; \mathrm{r}=0.5, \mathrm{p}<0.07$ ). If confirmed, the finding suggests a possible link between the size of visceral adipocytes and degree of lipolysis in subcutaneous adipocytes.
Finally, gene expression levels of LPL, HSL, and ATGL were different between subcutaneous and visceral adipose tissue for lean and morbidly obese men, whereas protein levels of HSL and ATGL were similar between the two depots.

\section{Discussion}

The present study evaluated in different fat depots whether dysregulation of enzymes involved in lipolysis or failure of mitochondria might play a predominant role in lipotoxicity. Our results demonstrate an increase of mtDNA content in visceral adipose tissue of morbidly obese men as well as an up-regulation of HSL and ATGL mRNA expression levels in visceral adipose tissue, which was, however, not accompanied by increased protein levels of HSL and ATGL.

The increase in mtDNA content in visceral adipose tissue is in line with a previous report [16]; although it might reflect a compensatory mechanism, we have no arguments for a functional change. Fat oxidation rates were not associated with mtDNA [16]. In our cohort, we neither did observe correlations between markers of lipolysis and mtDNA content, nor associations between mtDNA content and glucose tolerance status. Potential functional changes related to the increase of mtDNA in visceral adipose tissue of obese subjects should be investigated in future studies.

The increased gene expression levels of HSL and ATGL in the visceral adipose tissue of morbidly obese men is in line with some previous reports on HSL [17, 21] and ATGL [18], though in contrast to other publications $[17,19]$. An overview of the existing literature is presented in table 3. Most studies compared studies with mixed gender and different BMIs or with a different cut-off for insulin sensitivity. Studies with a 
a

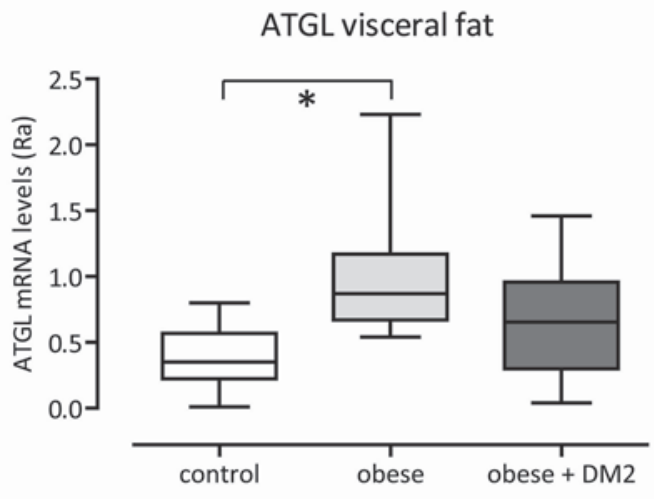

C

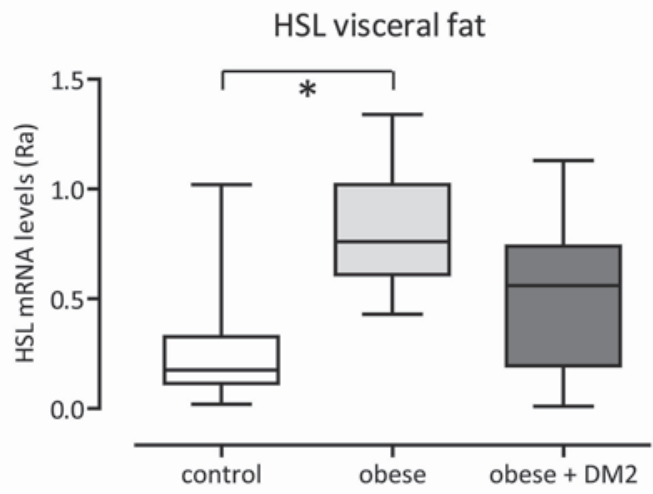

e

Fig. 3. Expression levels of ATGL mRNA, HSL mRNA and LPL mRNA obtained from adipose tissue of lean control, obese and obese + diabetes mellitus type 2 men of the visceral and subcutaneous depot (a-f). Correlation $(r=0.6, p<0.02)$ between the size of visceral adipocytes and ATGL mRNA in subcutaneous adipose tissue in lean controls (g), and correlation $(\mathrm{r}=0.5, \mathrm{p}<0.07)$ between the size of visceral adipocytes and HSL mRNA in subcutaneous adipose tissue in lean controls (h). $* \mathrm{p}<0.05$.

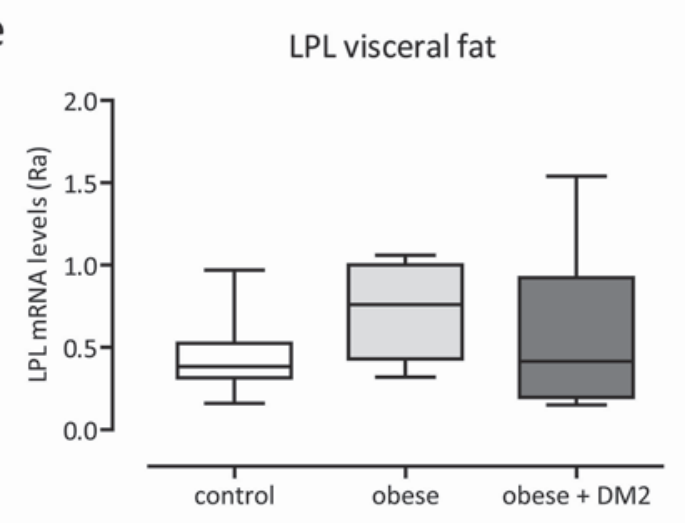

g

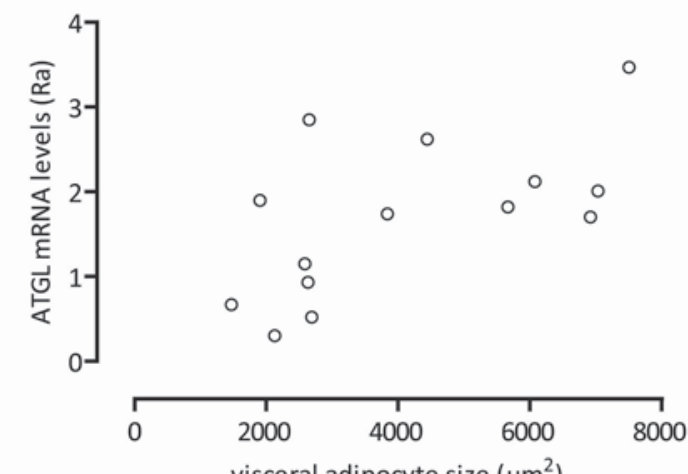

b

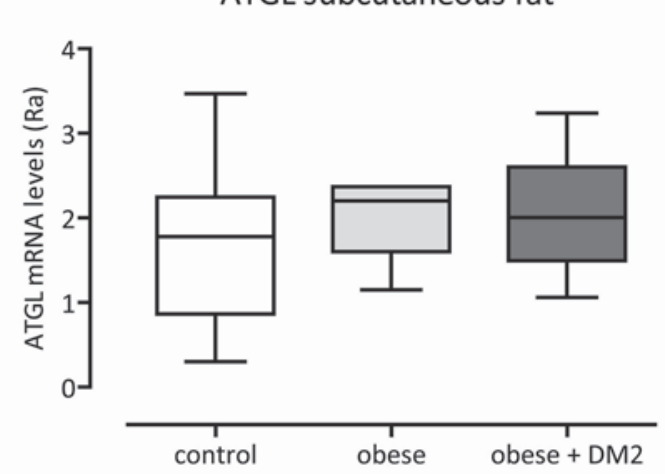

d

HSL subcutaneous fat

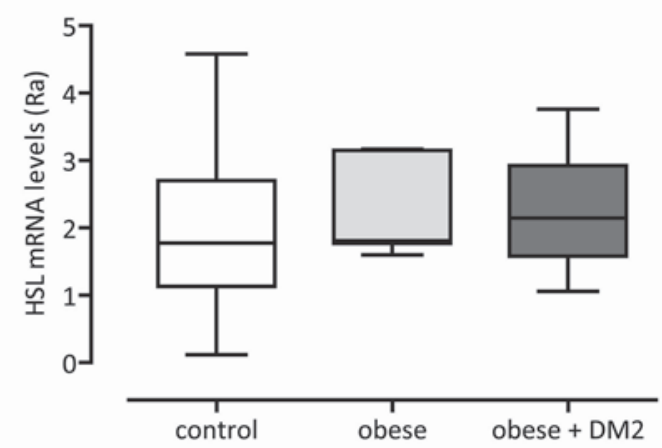

f

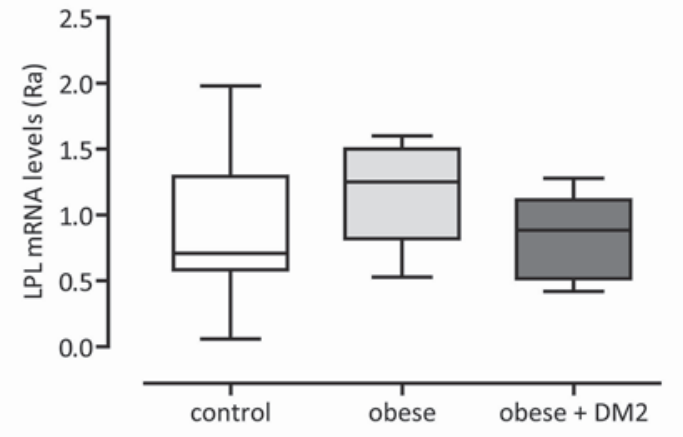

$\mathrm{h}$

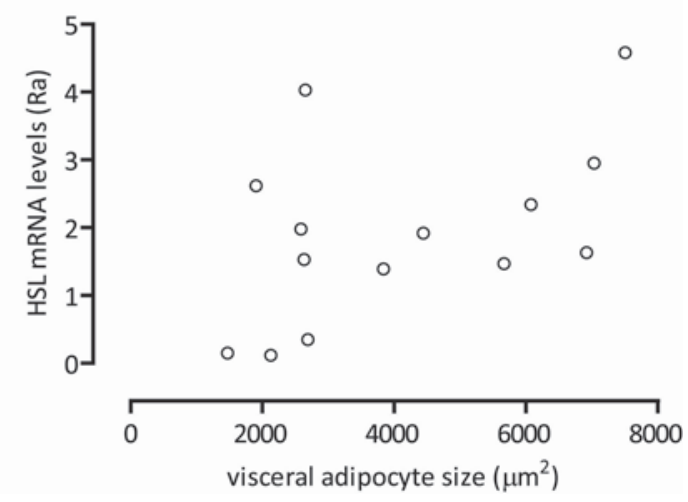


a

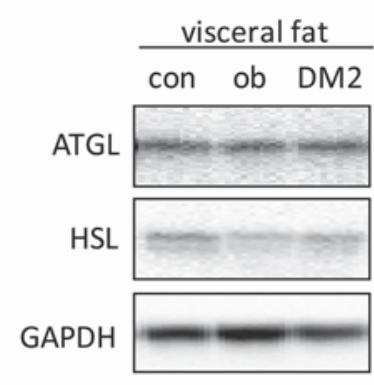

C

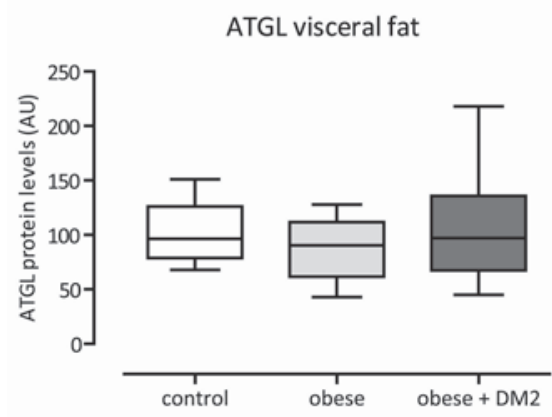

e

HSL visceral fat

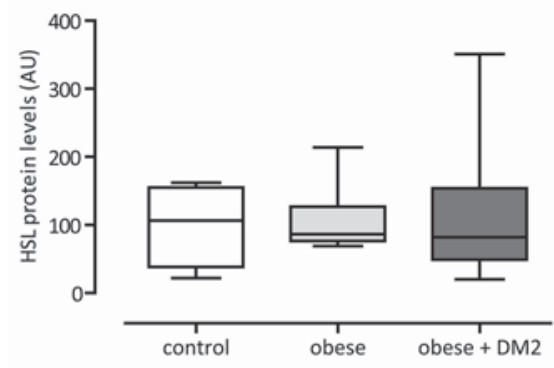

g tification of ATGL and HSL protein expression in adipose tissue biopsies of lean control (con), obese (ob) and obese + diabetes mellitus type 2 men of the visceral and subcutaneous depot (a-f). Equal loading of the blots was verified by reprobing the immunoblots with glyceraldehyde 3-phosphate (GAPDH) antibody. Correlation $(\mathrm{r}=0.6, \mathrm{p}<0.18)$ between the size of visceral adipocytes and ATGL protein in subcutaneous adipose tissue in lean controls (e). ${ }^{*} \mathrm{p}<0.05-0.10$.

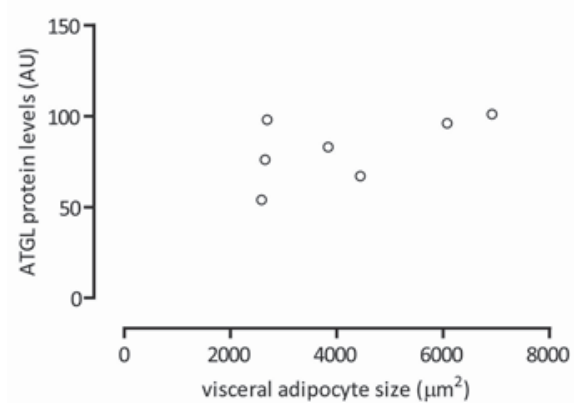

b

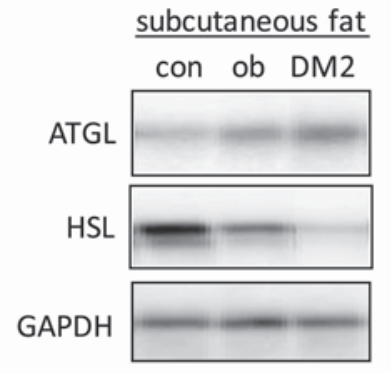

d

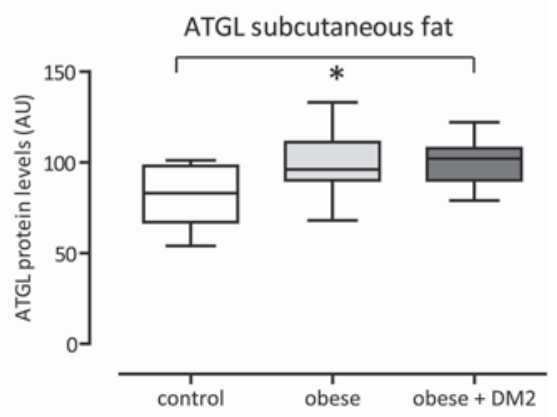

f

HSL subcutaneous fat

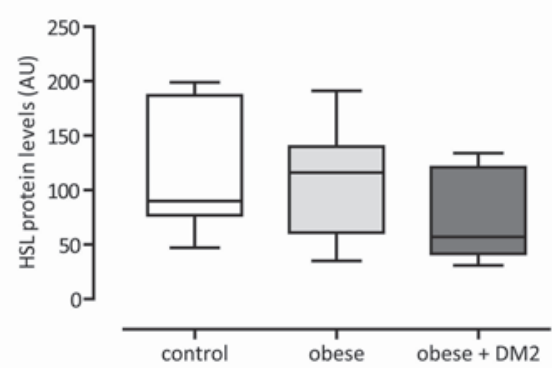

BMI difference $\leq 15 \mathrm{~kg} / \mathrm{m}^{2}$ between obese and controls showed decreased expression levels of HSL mRNA [19, 22, 23], whereas studies with a BMI difference $>15 \mathrm{~kg} / \mathrm{m}^{2}$ showed increased expression levels $[17,21]$. In the present study, men with BMI differences $>15 \mathrm{~kg} / \mathrm{m}^{2}$, with and without diabetes mellitus type 2, were compared. Diabetes mellitus type 2 might be regarded as a clear lipotoxic stage. Previous studies included both males and females or females alone [20, 21, 24], whereas gender might disturb a straightforward interpretation. Sex steroids affect lipolysis, adipocyte differentiation, and mitochondriogenesis [31, 32].

Increased expression of HSL and ATGL mRNA in visceral adipose tissue of obese subjects might point to an initiation of adaptation. Increased lipolysis in mice resulted in leanness and 


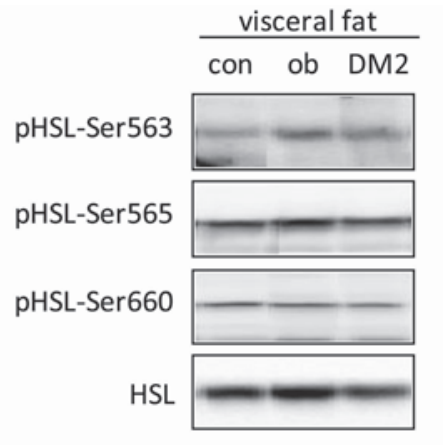

C

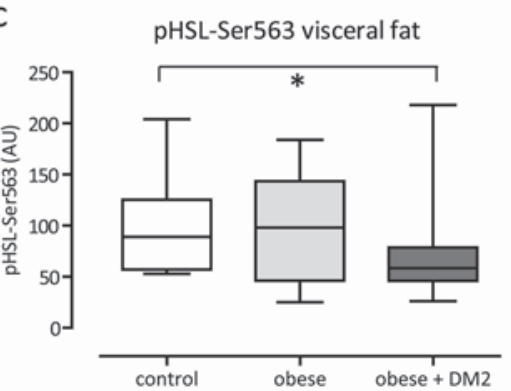

e

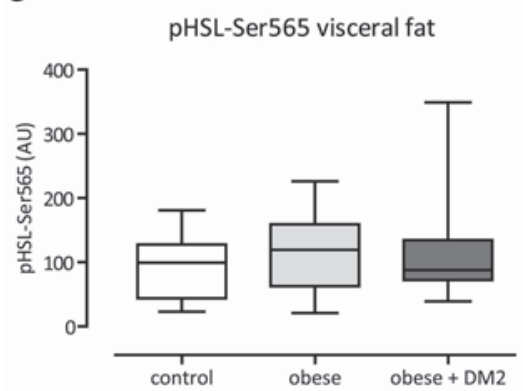

g

Fig. 5. Representative Western blots and quantification of phosphorylation of HSL on Ser563 (inhibitory), SerP565 and Ser660 in adipose tissue biopsies from of lean control (con), obese (ob) and obese + diabetes mellitus type 2 men of the visceral and subcutaneous depot (a-h). Equal loading of the blots was verified by reprobing the immunoblots with HSL antibody. *p $<0.05-0.10$.

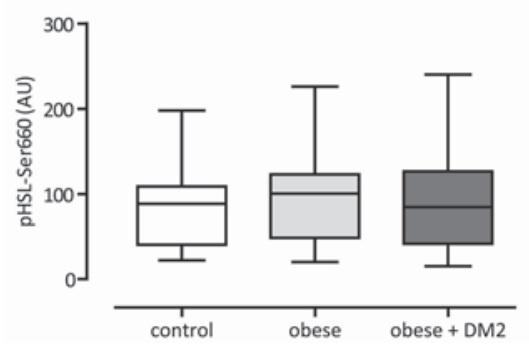

b

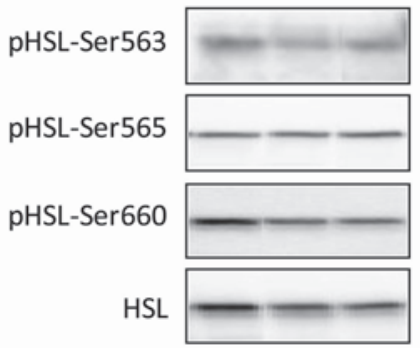

d

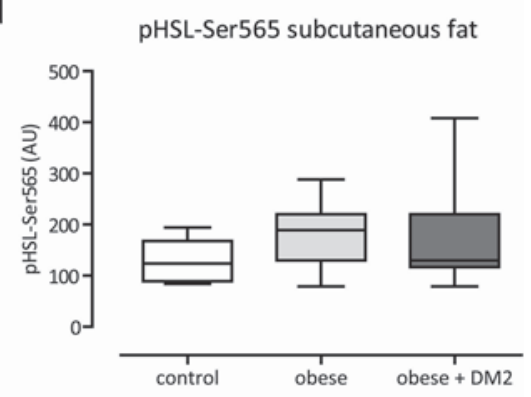

f

pHSL-Ser565 subcutaneous fat

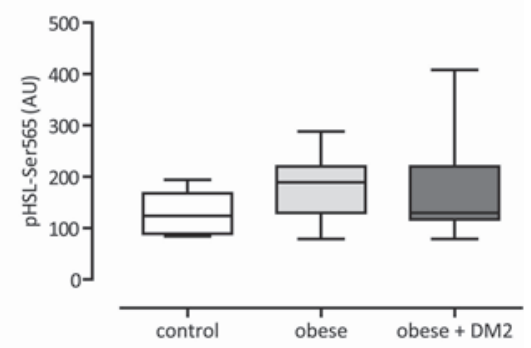

h

pHSL-Ser660 subcutaneous fat

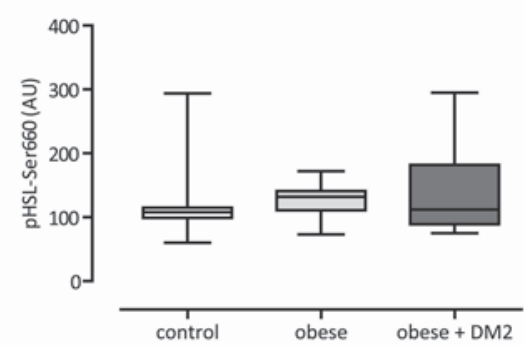

promoted free FA oxidation in adipocytes [33]. Increased ATGL-mediated lipolysis also affected macrophage function, suggesting an adaptive role of ATGL in immune response, inflammation or atherosclerosis [34]. Yet, in line with previous reports [18, 21], increased HSL and ATGL mRNA expression was not accompanied by increased protein levels of HSL and ATGL. Thus, posttranslational modifications of the genes may change adaptive initiation, and may explain the mismatch [35].

Protein expression of ATGL in visceral adipose tissue was similar in lean and morbidly obese men, and in line with results of literature $[18,20]$. We also found similar protein expression of HSL in visceral adipose tissue, though two studies on females reported decreased levels [20, 21]. Protein expression of HSL in subcutaneous adipose tissue was reported to be decreased in obese versus lean females (mixed gender populations) [20-24], whereas we did not find any difference in males, despite additional evaluation of phosphorylation of HSL on Ser563, SerP565, and Ser660. Protein expression does not necessarily reflect functional activity, though a certain degree of agreement has been suggested (table 3) [18, 22, 24]. In obesity, fasting serum TG might be somehow regarded as measure of lipid handling (or degree of lipotoxicity) [36, 37]. In the present study, fasting serum TG was positively correlated to the size of subcutaneous adipocytes in lean men as well as to 
Table 3. Comparison of gene and protein expression of HSL and ATGL between obese and lean subjects in previous studies

\begin{tabular}{|c|c|c|c|c|c|c|c|c|}
\hline \multirow[t]{2}{*}{ Study, year [reference no.] } & \multicolumn{2}{|c|}{ BMI, $\mathrm{kg} / \mathrm{m}^{2}$} & \multirow[t]{2}{*}{$\begin{array}{l}\text { Number of subjects } \\
\text { males/females }\end{array}$} & \multicolumn{2}{|c|}{$\begin{array}{l}\text { Hormone-sensitive } \\
\text { lipase (HSL) }\end{array}$} & \multicolumn{2}{|c|}{$\begin{array}{l}\text { Adipose triglyceride } \\
\text { lipase (ATGL) }\end{array}$} & \multirow[t]{2}{*}{ Lipolysis } \\
\hline & obese & lean & & $\begin{array}{l}\text { mRNA } \\
\text { expression }\end{array}$ & $\begin{array}{l}\text { protein } \\
\text { content }\end{array}$ & $\begin{array}{l}\text { mRNA } \\
\text { expression }\end{array}$ & $\begin{array}{l}\text { protein } \\
\text { content }\end{array}$ & \\
\hline \multicolumn{9}{|l|}{ Visceral adipose tissue } \\
\hline 2006 [17] & 42 & 24 & $32 / 61$ & $\uparrow$ & & $\leftrightarrow$ & & \\
\hline $2008[19]$ & 33 & 24 & $46 / 39$ & $\downarrow$ & & $\leftrightarrow$ & & \\
\hline $2009[20]^{*}$ & 24 & 23 & $00 / 20$ & & $\downarrow$ & & $\leftrightarrow$ & \\
\hline $2009[21]$ & 42 & 23 & $00 / 16$ & $\uparrow$ & $\downarrow$ & & & \\
\hline \multicolumn{9}{|l|}{ Subcutaneous adipose tissue } \\
\hline $1999[22]$ & 34 & 23 & $29 / 19$ & $\downarrow$ & $\downarrow$ & & & $\downarrow$ \\
\hline 2006 [17] & 39 & 24 & $00 / 96$ & $\downarrow$ & & $\leftrightarrow$ & & \\
\hline $2007[24]^{*}$ & 42 & 23 & $00 / 47$ & & $\downarrow$ & & $\leftrightarrow$ & $\downarrow$ \\
\hline $2007[18]$ & 32 & 25 & $06 / 10$ & & & $\uparrow$ & $\downarrow$ & $\downarrow$ \\
\hline 2008 [19] & 33 & 24 & $46 / 39$ & $\downarrow$ & & $\downarrow$ & & \\
\hline $2009[21]$ & 42 & 23 & $00 / 16$ & $\uparrow$ & $\downarrow$ & & & \\
\hline \multicolumn{9}{|c|}{$\begin{array}{l}\text { PCO = Poly cystic ovarian syndrome. } \\
\downarrow \text { Decrease versus obese. } \\
\uparrow \text { Increase versus obese. } \\
\leftrightarrow \text { no difference. } \\
* \text { Comparison between obese / PCO and lean subjects. } \\
* * \text { Comparison between (clamp measured) insulin-resis }\end{array}$} \\
\hline
\end{tabular}

the size of visceral adipocytes in morbidly obese men. Markers of subcutaneous lipolysis were positively correlated to the size of visceral adipocytes. Together, the findings suggest that an increase in visceral adipocyte size (and expansion of the visceral fat depot) could be related to saturation of subcutaneous adipocytes [38]. Quantitative expansion of the visceral adipose tissue may subsequently add to lipotoxicity, probably without prominent dysregulation of lipolytic enzymes or dysfunctioning of mitochondria of visceral adipose tissue.

The present study has some limitations. Our results are informative with respect to enzymes involved in basal lipolysis, though provide no information on the postprandial state. We did not assess the expression levels of potential co-activators of enzymes involved in lipolysis, such as perilipin, RIP140, and CGI-58, which have been implicated in the regulation of ATGL activity [39-41].

Furthermore, the current study is performed in men; i.e., results cannot be extrapolated to women. Finally, like most of the studies on the topic, the present study has a cross-sectional design, with its well known limitations with respect to causal inference.

\section{Conclusion}

To better understand the development of lipotoxicity in morbidly obese men, we evaluated visceral and subcutane- ous adipose protein expression of HSL or ATGL, which was not different compared to lean men. mtDNA content of visceral adipose tissue was increased in morbidly obese men. It is therefore concluded that 'normal physiology' of the increased amount of visceral fat might be more important for lipotoxicity than dysregulation of involved lipolytic enzymes or of adipocyte mitochondria. Future studies might also be directed at evaluation of functional activity of visceral adipocyte mitochondria, lipolysis of different depots in non-fasting conditions, and at the role of daily serum TG clearance.

\section{Acknowledgements}

The authors are indebted to Birgit Knobloch for excellent technical assistance by performing all western blots, and to Dorothy Van Limbergen, Saskia De Groote, Inge Vandenbroucke and to Kaatje Toye for their invaluable practical assistance to the study. This work was supported by the EU European Cooperation in the field of Scientific and Technical Research (COST) Action BM0602 (Adipose tissue: A key target for prevention of the metabolic syndrome). This work was further supported by a grant from Eli Lilly Benelux NV.

\section{Disclosure Statement}

No potential conflicts of interest relevant to this article were reported. 


\section{References}

1 Stefan N, Kantartzis K, Machann J, Schick F, Thamer C, Rittig K, Balletshofer B, Machicao F, Fritsche A, Häring HU: Identification and characterization of metabolically benign obesity in humans. Arch Intern Med 2008;168:1609-1616.

$\checkmark 2$ Oral EA, Simha V, Ruiz E, Andewelt A, Premkumar A, Snell P, Wagner AJ, DePaoli AM, Reitman ML, Taylor SI, Gorden P, Garg A: Leptin-replacement therapy for lipodystrophy. N Engl J Med 2002; 346:570-578.

3 Frayn KN: Adipose tissue as a buffer for daily lipid flux. Diabetologia 2002;45:1201-1210.

4 Koutsari C, Dumesic DA, Patterson BW, Votruba $\mathrm{SB}$, Jensen MD: Plasma free fatty acid storage in subcutaneous and visceral adipose tissue in postabsorptive women. Diabetes 2008;57:1186-1194.

5 Lafontan M, Langin D: Lipolysis and lipid mobilization in human adipose tissue. Prog Lipid Res 2009;48:275-297.

6 Pilz S, März W: Free fatty acids as a cardiovascular risk factor. Clin Chem Lab Med 2008;46:429-434.

7 Jensen MD: Role of body fat distribution and the metabolic complications of obesity. J Clin Endocrinol Metable 2008;93(suppl 1):S57-S63.

8 Manolopoulos KN, Karpe F, Frayn KN: Gluteofemoral body fat as a determinant of metabolic health. Int J Obes (Lond) 2010;34:949-959.

$\checkmark$ Wajchenberg BL: Subcutaneous and visceral adipose tissue: their relation to the metabolic syndrome. Endocr Rev 2000;21:697-738.

-10 Nielsen S, Guo Z, Johnson CM, Hensrud DD, Jensen MD: Splanchnic lipolysis in human obesity. J Clin Invest 2004;113:1582-1588.

11 Garaulet M, Hernandez-Morante JJ, Lujan J, Tebar FJ, Zamora S: Relationship between fat cell size and number and fatty acid composition in adipose tissue from different fat depots in overweight/ obese humans. Int J Obes (Lond) 2006;30:899-905.

12 Weyer C, Foley JE, Bogardus C, Tataranni PA, Pratley RE: Enlarged subcutaneous abdominal adipocyte size, but not obesity itself, predicts type II diabetes independent of insulin resistance. Diabetologia 2000;43:1498-1506.

13 Cinti S, Mitchell G, Barbatelli G, Murano I, Ceresi E, Faloia E, Wang S, Fortier M, Greenberg AS, Obin MS: Adipocyte death defines macrophage localization and function in adipose tissue of obese mice and humans. J. Lipid Res 2005;46:2347-2355.

14 Skurk T, Alberti-Huber C, Herder C, Hauner H: Relationship between adipocyte size and adipokine expression and secretion. J Clin Endocrinol Metable 2007;92:1023-1033.

15 Maassen JA, Romijn JA, Heine RJ: Fatty acid-induced mitochondrial uncoupling in adipocytes as a key protective factor against insulin resistance and beta cell dysfunction: a new concept in the pathogenesis of obesity-associated type 2 diabetes mellitus. Diabetologia 2007;50:2036-2041.

16 Lindinger A, Peterli R, Peters T, Kern B, von Flüe M, Calame M, Hoch M, Eberle AN, Lindinger PW. Mitochondrial DNA content in human omental adipose tissue. Obes Surg 2010;20:84-92.
Mairal A, Langin D, Arner P, Hoffstedt J: Human adipose triglyceride lipase (PNPLA2) is not regulated by obesity and exhibits low in vitro triglyceride hydrolase activity. Diabetologia 2006;49:16291636.

18 Steinberg GR, Kemp BE, Watt MJ: Adipocyte triglyceride lipase expression in human obesity. Am J Physiol Endocrinol Metable 2007;293:E958-E964.

19 Berndt J, Kralisch S, Klöting N, Ruschke K, Kern M, Fasshauer M, Schön MR, Stumvoll M, Blüher M: Adipose triglyceride lipase gene expression in human visceral obesity. Exp Clin Endocrinol Diabetes 2008;116:203-210

20 Seow KM, Tsai YL, Hwang JL, Hsu WY, Ho LT, Juan CC: Omental adipose tissue overexpression of fatty acid transporter CD36 and decreased expression of hormone-sensitive lipase in insulin-resistant women with polycystic ovary syndrome. Hum Reprod 2009;24:1982-1988.

21 Ray H, Pinteur C, Frering V, Beylot M, Large V: Depot-specific differences in perilipin and hormone-sensitive lipase expression in lean and obese. Lipids Health Dis 2009;8:58-68.

22 Large V, Reynisdottir S, Langin D, Fredby K, Klannemark M, Holm C, Arner P: Decreased expression and function of adipocyte hormonesensitive lipase in subcutaneous fat cells of obese subjects. J Lipid Res 1999;40:2059-2066.

23 Jocken JW, Langin D, Smit E, Saris WH, Valle C, Hul GB, Holm C, Arner P, Blaak EE: Adipose triglyceride lipase and hormone-sensitive lipase protein expression is decreased in the obese insulin-resistant state. J Clin Endocrinol Metab 2007;92:2292-2299

24 Rydén M, Jocken J, van Harmelen V, Dicker A, Hoffstedt J, Wirén M, Blomqvist L, Mairal A, Langin D, Blaak E, Arner P: Comparative studies of the role of hormone-sensitive lipase and adipose triglyceride lipase in human fat cell lipolysis. Am J Physiol Endocrinol Metable 2007;292:E1847-E1855.

25 Iozzo $\mathrm{P}$, Bucci M, Roivainen A, Någren K, Järvisalo MJ, Kiss J, Guiducci L, Fielding B, Naum AG, Borra R, Virtanen K, Savunen T, Salvadori PA, Ferrannini E, Knuuti J, Nuutila P: Fatty acid metabolism in the liver, measured by positron emission tomography, is increased in obese individuals. Gastroenterology 2010;139:846-856.

26 Genuth S, Alberti KG, Bennett P, Buse J, Defronzo R, Kahn R, Kitzmiller J, Knowler WC, Lebovitz H, Lernmark A, Nathan D, Palmer J, Rizza R, Saudek C, Shaw J, Steffes M, Stern M, Tuomilehto J, Zimmet P; Expert Committee on the Diagnosis and Classification of Diabetes Mellitus: Follow-up report on the diagnosis of diabetes mellitus. Diabetes Care 2003;26:3160-3167.

27 Tchoukalova YD, Harteneck DA, Karwoski RA, Tarara J, Jensen MD: A quick, reliable, and automated method for fat cell sizing. J Lipid Res 2003;44:1795-1801.

28 Vandesompele J, De Preter K, Pattyn F, Poppe B, Van Roy N, De Paepe A, Speleman F: Accurate normalization of real-time quantitative RT-PCR data by geometric averaging of multiple internal control genes. Genome Biol 2002;3(7):RESEARCH0034.
Reiling E, Ling C, Uitterlinden AG, Van't Riet E, Van't Riet E, Welschen LM, Ladenvall C, Almgren P, Lyssenko V, Nijpels G, van Hove EC, Maassen JA, de Geus EJ, Boomsma DI, Dekker JM, Groop L, Willemsen G, 't Hart LM: The association of mitochondrial content with prevalent and incident type 2 diabetes. J Clin Endocrinol Metable 2010;95:1909-1915.

30 Szuhai K, Ouweland J, Dirks R, Lemaître M, Truffert J, Janssen G, Tanke H, Holme E, Maassen J, Raap A: Simultaneous A8344G heteroplasmy and mitochondrial DNA copy number quantification in myoclonus epilepsy and ragged-red fibers (MERRF) syndrome by a multiplex molecular beacon based real-time fluorescence PCR. Nucleic Acids Res 2001;29:E13.

31 Ruige JB: Does low testosterone affect adaptive properties of adipose tissue in obese men? Arch Physiol Biochem 2011;117:18-22.

32 Klinge CM: Estrogenic control of mitochondrial function and biogenesis. J Cell Biochem 2008;105:1342-1351.

33 Ahmadian M, Wang Y, Sul HS: Lipolysis in adipocytes. Int J Biochem Cell Biol 2010;42:555-559.

34 Chandak PG, Radovic B, Aflaki E, Kolb D, Buchebner M, Fröhlich E, Magnes C, Sinner F, Haemmerle G, Zechner R, Tabas I, Levak-Frank S, Kratky D: Efficient phagocytosis requires triacylglycerol hydrolysis by adipose triglyceride lipase. J Biol Chem 2010;285:20192-20201

35 Xu G, Sztalryd C, Lu X, Tansey JT, Gan J, Dorward $\mathrm{H}$, Kimmel AR, Londos C: Post-translational regulation of adipose differentiation-related protein by the ubiquitin/proteasome pathway. J Biol Chem 2005;280:42841-428417.

36 Ruige JB, Van Gaal LF: Low fasting triglycerides: hallmark of the healthy large hip? Obesity (Silver Spring) 2009;17:1621-1626.

37 Tirosh A, Shai I, Bitzur R, Kochba I, Tekes-Manova D, Israeli E, Shochat T, Rudich A: Changes in triglyceride levels over time and risk of type 2 diabetes in young men. Diabetes Care 2008;31:2032-2037.

38 Kim SH, Reaven G: Obesity and insulin resistance: an ongoing saga. Diabetes 2010;59:2105-2107.

39 Borg ML, Andrews ZB, Duh EJ, Zechner R, Meikle PJ, Watt MJ: Pigment epithelium-derived factor regulates lipid metabolism via adipose triglyceride lipase. Diabetes 2011;60:1458-1466.

40 Ho PC, Chuang YS, Hung CH, Wei LN: Cytoplasmic receptor-interacting protein 140 (RIP140) interacts with perilipin to regulate lipolysis. Cell Signal 2011;23:1396-1403.

41 Miyoshi H, Perfield JW 2nd, Souza SC, Shen WJ, Zhang HH, Stancheva ZS, Kraemer FB, Obin MS, Greenberg AS: Control of adipose triglyceride lipase action by serine 517 of perilipin A globally regulates protein kinase A-stimulated lipolysis in adipocytes. J Biol Chem 2007;282;996-1002. 